postulated that the pancreas possessed a most unusual degree of sensitivity to radiation carcinogenesis. In the absence of supporting data it would be unwise to conclude that this increased mortality is a specific radiation effect. If confirmatory data are not forthcoming it may be presumed that the present findings are due to the operation of chance.

\section{Applicability of the Findings}

It is clear that under modern working conditions-that is, the provision of and adherence to adequate protective measures-the personnel of medical radiological departments have not run any substantial risk of (1) a reduction in the expectation of life from a non-specific ageing effect, or (2) an increased mortality from the common forms of cancer. These conclusions, however, are based on the study of fewer than 1,400 men, and in a group this size a very small risk would not have been easy to detect. Much larger numbers of persons are employed in industrial plants associated with the use of radiation sources of various kinds, and there can be no doubt that these numbers will increase considerably in the ensuing decades. These men are, on the whole, exposed to more energetic sources of radiation, and in some cases to types of radiations-for example, fast neutrons-for which the relative biological efficiency for the induction of delayed radiation effects may have a value greater than that of $\gamma$ rays or medium voltage $x$ rays. It is therefore necessary to be cautious in generalizing from the present experience.

The findings do, however, suggest that, so long as care is taken to introduce and observe the recommended measures of protection, the long-term somatic risks of radiation will be very small.

\section{Summary and Conclusions}

A study has been made of the causes of death of 1,377 male British radiologists during a 60 -year period from 1897 to 1957.

A comparison of the observed and expected numbers of deaths from all causes provides no evidence that occupational exposure to ionizing radiations has caused a detectable non-specific shortening of the expectation of life. This is particularly striking, since the population includes most of the pioneer British radiologists, many of whom are known to have suffered from specific effects of over-exposure-that is, radiation dermatitis and skin cancer.

A significant excess of cancer deaths was found among those men entering the practice of radiology before 1921, the year in which the first committee to advise on protection was formed. The excess was confined to tumours of the skin and pancreas and (possibly) leukaemia.

No excess mortality from cancer was found in those men entering radiology subsequent to 1920 ; but it is as yet too early to be sure that the cancer hazard has been eliminated.

The suggestion that this survey should be undertaken was made by the External Radiation Subcommittee of the Medical Research Council's Committee on Protection against Ionizing Radiations, and we should like to record our indebtedness to the chairman, Dr. J. F. Loutit, and the other members of the subcommittee We would like to thank the Council of the British Institute of Radiology and the Faculty of Radiologists for permission to make use of their records, and the members of their staffs for their ready assistance. We would like also to thank the General Medical Council, the British Medical Association, and the many persons who helped us to obtain information about the individual radiologists, and particularly Mrs. Tana Lloyd, Miss Flora Callaby, and Mrs. Marie Kidd, of the staff of the Medical Research Council, who collected the greatest part of the data.

\section{REFERENCES}

Blair, H. A. (1956). Data Pertaining to Shortening of Life Span by Ionizing Radiation. University of Rochester, U.R. $\mathbf{4 4 2}$.

Court Brown, W. M., and Doll, R. (1957). Rep. med. Res. Coun. (Lond.), No. 295. H.M.S.O.., London

Dublin. L. I., and Spiegelman, M.

Failla, G. (1957). Radiology, 69, 23.

Failla, G. (1957). Radiology', 69, 23.

Godfrey, B. E., Osborn, S. B., and Temple

Hunter, D. (1955). The Diseases of Occupations. English Univ. Press, London.

Hursh, J. B. (1956). The Effect of Ionizing Radiation on Longevity. University of Rochester. U.R. 506 .

Jones, H. B. (1957). The Nature of Radioactive Fall-out and its Effects on Man. U.S. Government Printing Office, Washington.

ordan, C. W. (1952). Life Contingencies. Society of Actuaries, Chicago.

McKenzie, A., Case, R. A. M., and Pearson, J. T. (1957). Studies on Medical and Population Subjects No. 13. Cancer Statistics for England and Wales, 1901-1955. H.M.S.O., London.

March, H. C. (1950). Amer. J. med. Sci., 220, 282.

Mole, R. H. (1957). Nature (Lond.), 180, 456

National Academy of Sciences: National Research Council (1956). The Biological Effects of Atomic Radiation. Washington.

Registrar-General for England and Wales (1923). Supplement to the Seventyfifth Annual Report. Part IV. Mortality of Men in Certain Occupation in the Three Years 1910, 1911, 1912. H.M.S.O., London.

In the Three rears Fertility and Infant Mortality. H.M.S.O., London.

(1938). Decennial Supplement, 1931. Part Ila. Occupational Mortalty. H.M.S.O.. London

(1958). Decennial Supplement, 1951. Part II. Occupational Mortality. H.M.S.O., London.

Seltser, R., and Sartwell, P. E. (1958). J. Amer. med. Ass., 166, 585

Warren, S. (1956). Ibid., 162, 464.

\section{PRELIMINARY REPORT ON MASS VACCINATION OF MAN WITH LIVE ATTENUATED POLIOMYELITIS VIRUS IN THE BELGIAN CONGO AND RUANDA-URUNDI*}

BY

G. COURTOIS, M.D.

Director, Laboratoire Médical, Stanleyville, Belgian Congo

A. FLACK, M.D.

Medical Director, Clinton Farms, Clinton, N.J., U.S.A.

G. A. JERVIS, M.D.

Director of Laboratories, Letchworth Village, New York State Department of Mental Health, Thiels, N.Y., U.S.A.

\section{H. KOPROWSKI, M.D.}

Director, the 'Wistar Institute, Philadelphia, Pa., U.S.A.; previously Assistant Director, Virus and Rickettsial Research Lederle Laboratories, Pearl River, N.Y., U.S.A.

AND

G. NINANE, M.D.

Laboratoire Médical, Stanleyville, Belgian Congo

Vaccination of man by oral administration of live attenuated poliomyelitis virus has been employed in clinical trials in the United States of America (Koprowski, 1955 ; Koprowski et al., 1952, 1956a, 1956b). Several attenuated strains representing the three types of poliovirus were investigated, and the number of persons vaccinated in each trial was kept purposely small until a strain could be found which would satisfy laboratory and clinical criteria of safety. Such strains finally became available (Koprowski, 1957), and therefore it was decided to organize a clinical trial on a larger scale than had been previously attempted.

While participating in a rabies course organized by the World Health Organization in 1955 in Muguga, Kenya, one of the authors (H. K.) had the opportunity, through

*Part of the work mentioned in this paper was supported by a research grant (E-1799) from the National Institutes of Health, U.S. Public Health Service. 
the kindness of Dr. T. J. Wiktor, Veterinary Service, Belgian Congo, to contact one of the other authors (G. C.) and to propose a programme of experiments for the evaluation of attenuated strains of poliovirus in chimpanzees. Following the successful outcome of preliminary negotiations, a chimpanzee colony was established in Lindi (Stanleyville, Belgian Congo) and experiments were initiated after necessary permission and financial support had been obtained from the Government of the Belgian Congo.

In the course of this work, results of which will be published elsewhere (Courtois et al., 1958), caretakers of the animal colony were vaccinated with attenuated virus in order to protect them against possible exposure to the virulent poliomyelitis used for challenge of vaccinated chimpanzees. The successful outcome of the programme for immunization of the caretakers prompted us to undertake clinical trials in the Belgian Congo on a much larger scale than had been attempted so far. Authorization to conduct such trials was obtained in the second half of 1957 from Dr. Charles Dricot, Physician-in-Chief, Government of Belgian Congo, to whom we express gratitude.

\section{Material and Methods}

Virus Strains.-The Chat strain of type 1 poliovirus and the Fox III strain of type 3 poliovirus were chosen for vaccination purposes (Koprowski, 1957). The large pools representing each strain were prepared in the Laboratories of the Wistar Institute, Philadelphia, $\mathrm{Pa}$., and tested for lack of virulence in rhesus monkeys injected intracerebrally and intraspinally and in chimpanzees injected intraspinally (the latter tests were done in Lindi Camp, Belgian Congo). None of the intracerebrally injected monkeys and intraspinally injected chimpanzees (five animals were injected with aliquots of undiluted material representing each pool) showed signs of illness, and histological examination of the central nervous system showed only one chimpanzee with mild lesions of the spinal cord suggestive of poliomyelitis infection (Fox III). Signs of polio infection were found in some of the rhesus monkeys injected intraspinally with the undiluted material; this, however, has not deterred us from using these strains for mass vaccination purposes, as there is no strain of attenuated poliovirus available anywhere in the world completely devoid of pathogenic properties when injected intraspinally into rhesus or cynomolgus monkeys (Sabin, 1957).

For additional testing, aliquots of each pool were injected into 20 rabbits, 14 infant mice, 5 guineapigs, and 12 adult mice in order to rule out the presence of other viral agents, such as B virus, lymphocytic choriomeningitis, and Coxsackie viruses. Although the material was filtered through bacteria-retaining filters, rigid tests for bacterial sterility were completed before the virus pools were used in man.

The efficiency of each virus preparation was finally checked by feeding the virus to a small group of infants and adults in the United States of America. These indi- viduals had no antibodies against the type of virus administered, and in no instance was there a reaction of any kind. This procedure also made it possible to determine the minimum immunizing dose of the virus, which was found to be $10^{3.7} \mathrm{TCD}_{50}$ (tissue culture doses) for non-immune children and adults and $10^{5.0} \mathrm{TCD}_{50}$ for infants less than 1 month old.

Method of Administration of Virus to Man.-The virus preparation was administered either in capsule (Koprowski et al., 1956b) or in liquid form. Administration of the liquid was accomplished either by immersing an automatic pipette inte a large container of virus preparation and squirting $1 \mathrm{ml}$. direct into the mouth of the recipient or by simply using a tablespoon. The approximate minimum dose fed to each individual was $10^{5.3} \mathrm{TCD}_{50}$ of each strain. Throughout the above period the container of virus suspension was kept at $4^{\circ} \mathrm{C}$.

Determination of Neutralizing Antibodies.-In localities where prophylactic vaccination was contemplated a certain number of individuals chosen at random were bled and the presence of neutralizing antibodies against all three types of poliovirus was determined by means of the immuno-inactivation test described by Gard (1957). Immunization of the total population of the community was decided upon only if $12 \%$ or more of the sera collected were found to have no antibodies against a given type of virus.

Since type 1 virus was incriminated in most outbreaks of paralytic poliomyelitis, including those in the Belgian Congo (see below), it was decided to give priority to vaccination with attenuated type 1 virus wherever it was statistically feasible.

\section{Vaccination of Populations in the Absence of a Poliomyelitis Epidemic}

Localities where trials took place are shown on the accompanying map of the Belgian Congo, and the total number of persons vaccinated is given in Table $I$.

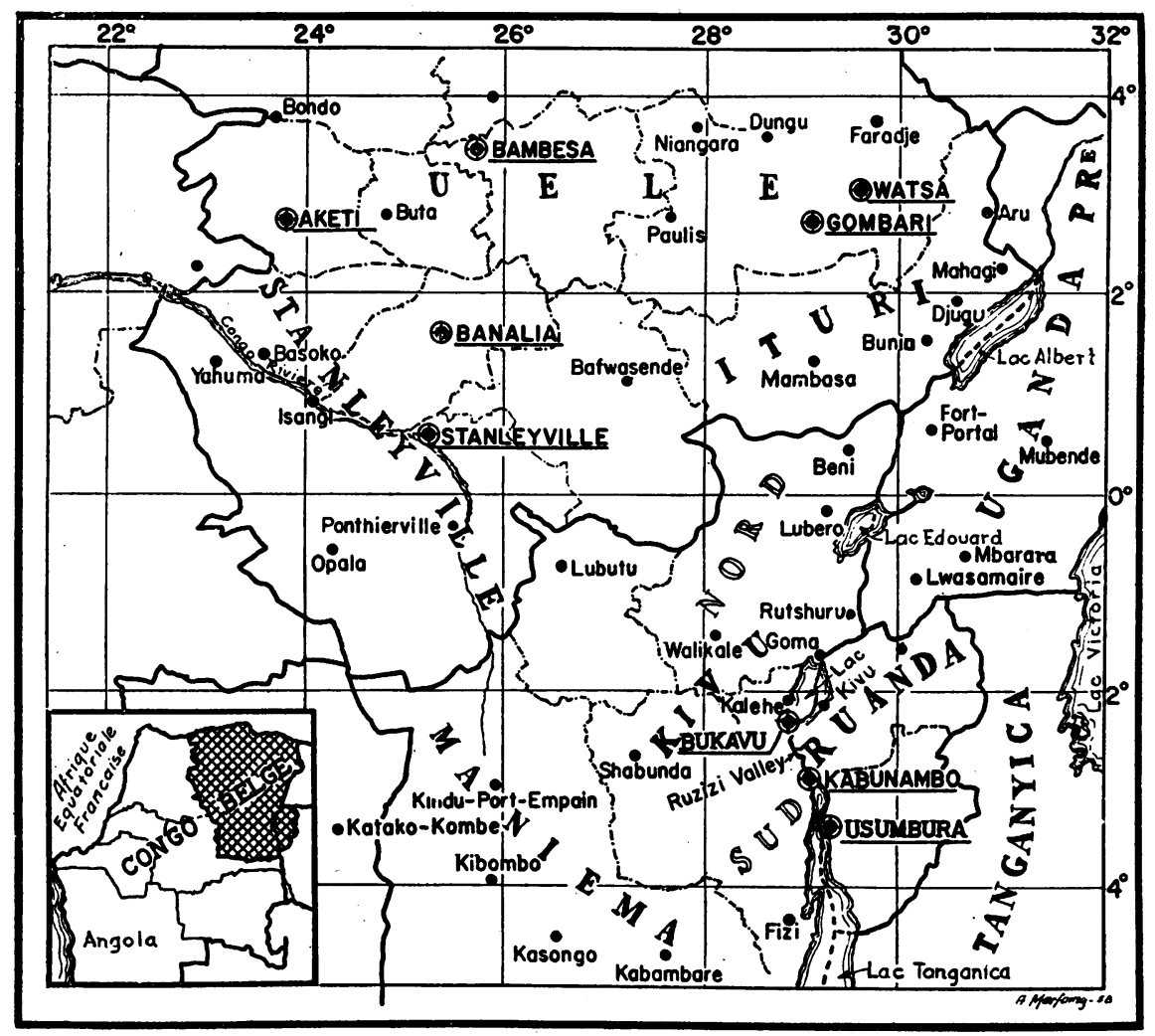

Map showing locations in the Belgian Congo and Ruanda-Urundi (Aketi, Stanleyville, Ruzizi Valley, Banalia, Gombari, Watsa, and Bambesa) where mass vaccination trials with live attenuated poliovirus were conducted. The small insert map shows the same region (cross-hatched) in relation to the surrounding geographical area. 
TABLE I.-Number of Persons Vaccinated with Live Attenuated Poliovirus* in Various Communities in the Belgian Congo and Ruanda-Urundi

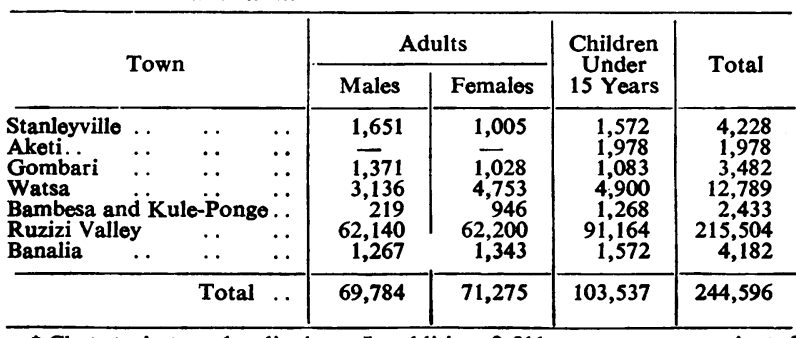

* Chat strain type 1 poliovirus. In addition, 2,511 persons were vaccinated with type 3 poliovirus, Fox III strain; 134 men, 130 women, and 2,247 children

Aketi.-Here 1,978 school-children, most of them between 5 and 15 years old, were chosen for vaccination. One hundred serum specimens obtained by random bleeding of future recipients of the vaccine were examined by means of neutralization tests ; $15 \%$ were found to have no antibodies against type 1 and $43 \%$ no antibodies against type 3 virus. The Chat strain virus preparation was administered in capsules to 1,978 recipients (see Table I), and those who showed no antibodies against this type were bled again two months after vaccination. During that period rigid clinical observations failed to show any signs of illness which could be attributed to the vaccine. All but two of the vaccinated children who had no antibodies to type 1 virus before vaccination developed determinable serum antibodies against type 1 poliovirus following vaccination. Six months after vaccination with type 1 virus, the Fox III strain of type 3 virus was administered to the same population. Again no signs of illness were observed, and all but two who had no antibodies to type 3 virus before vaccination developed type 3 antibodies following vaccination.

Stanleyville.-During the 12 months preceding the mass trial at Ruzizi Valley (see below) infants, children, and adults of European and native origin living in Stanleyville were vaccinated with Chat and Fox III virus strains. A large group of school-children, mostly of European origin, were vaccinated with living virus every week during that period of time. The total number was 4,228 (see Table I), and careful clinical observations failed again to reveal any detrimental effects of the vaccines.

Ruzizi Valley.-A mass vaccination trial was decided upon after preliminary testing of 84 serum specimens collected at random from inhabitants of Ruzizi Valley revealed that $12 \%$ had no neutralizing antibodies against type 1 virus and $15 \%$ had no antibodies against type 3 virus. The trial began on February 24, 1958, and was completed by April 10. The native population were informed by their chiefs about the vaccination project and assembled daily at previously fixed rally points. From 3,000 to 11,000 persons were vaccinated daily by members of one or two vaccination teams. The vaccine used was a preparation of Chat type 1 poliovirus, given orally as a liquid. Included in the trial were two missionary schools whose pupils were divided into two groups, one receiving the vaccine and the other a placebo. Medical authorities were asked to report any occurrence of illness which could be attributed to vaccination, but none was reported. For evaluation purposes 450 blood specimens were obtained at random before vaccination from individuals who were less than 15 years old. The total number of children and adults vaccinated in the Ruzizi Valley was 215,504, as indicated in Table $I$.

\section{Vaccination Against Poliomyelitis in Face of an Epidemic}

Banalia.-Between the end of November, 1957, and the first days of January, 1958, eight cases of paralytic poliomyelitis in native infants and children less than 5 years old were observed in Banalia. Signs of paralysis in the latest two cases were observed five days before vaccination was started. The total population of Banalia was 4,182, and the number of children less than 5 years old was 674 (Table II). Since all cases of paralytic poliomyelitis
TABLE II.-Age and Sex Distribution of Inhabitants of Banalia Vaccinated with Live Attenuated Poliovirus

\begin{tabular}{|c|c|c|c|c|}
\hline \multicolumn{2}{|l|}{ Age } & Males & Femalos & Total \\
\hline $\begin{array}{ll}<5 \text { years } & . \\
\text { 5-14 } & \ldots \\
\text { Adults"(over } & 14 \text { years) }\end{array}$ & $\begin{array}{ll}. & . \\
\because & .\end{array}$ & $\begin{array}{r}312 \\
497 \\
1,267\end{array}$ & $\begin{array}{r}362 \\
401 \\
1,343\end{array}$ & $\begin{array}{r}674 \\
898 \\
2,610\end{array}$ \\
\hline & Total ... & 2,076 & 2,106 & 4,182 \\
\hline
\end{tabular}

occurred in children less than 5 years old, the actual incidence for that age group was $1.2 \%$.

Following the recommendation of the Expert Committee on Poliomyelitis of the World Health Organization (Report of the Expert Committee, 1957) and upon the request of the Médecin Provincial of Province Oriental, Chat type 1 virus was administered to every inhabitant of Banalia. Blood specimens were obtained before vaccination, including samples from three of the persons who had contracted paralytic poliomyelitis most recently. Sera from these three patients were examined by means of a complement-fixation test for the presence of antibodies against antigens representing each of the three types of virus. No antibodies were discovered against type 2 and type 3 viruses, but sera in dilutions $1: 16,1: 16$, and $1: 32$ were found to fix complement in the presence of type 1 antigen; the outbreak would therefore seem to have been caused by type 1 virus. Not a single case of paralytic poliomyelitis was observed in Banalia following oral vaccination with the Chat type 1 strain of virus.

Gombari, Watsa, and Bambesa.-Within three weeks of the occurrence of the last paralytic case in Banalia, outbreaks of paralytic poliomyelitis were reported in Gombari, Watsa, and Bambesa. In Gombari, a village of 3,482 inhabitants, 12 cases of paralysis were reported. In Watsa, out of 12,789 inhabitants, two cases were observed. In Bambesa seven cases were noted among 2,350 inhabitants. Live attenuated Chat type 1 virus was administered within five days of the occurrence of the last reported case of paralysis. Again, as in Banalia, every inhabitant of Gombari, Watsa, and Bambesa received the vaccine. After the fourth post-vaccination day no new cases of paralysis were observed in these localities.

\section{Summary and Conclusions}

A total of 244,596 inhabitants of the Belgian Congo and Ruanda-Urundi of both sexes and all ages were vaccinated with live attenuated Chat strain type 1 poliovirus by the oral route. Of these, 2,511 also received the Fox III strain of attenuated type 3 virus. No sickness was reported following administration of the virus.

Figures based on a preliminary survey of neutralizing antibodies in the population who were later vaccinated indicated that $12 \%$ had no antibodies against the type 1 virus which was used as vaccine. More exact data on the proportion of polio-susceptible individuals will be obtained when laboratory tests on the large number of sera collected during the actual trial are completed.

Following recommendation of the Expert Committee on Poliomyelitis of the World Health Organization, the live Chat type 1 virus was administered during four epidemic outbreaks of paralytic poliomyelitis in the Belgian Congo. After vaccination no more cases of paralysis were reported in the four localities involved in the outbreaks.

We thank all the officials who gave us permission to carry out the mass vaccinations: Dr. Dricot, Physician-in-Chief, Government of the Belgian Congo; Dr. Gillet, Chief of the Hygiene Service at Bukavu, under whose control the Belgian Government has placed the experiments; Dr. Claessens. Dr. Gillart, and Dr. Van Daele, Provincial Physicians. We especially thank Mr. Brakel, who took part in the vaccination campaign during the epidemics. We likewise thank all those who contributed directly to the vaccination programme: Dr. Meyus, Dr. Dewolf, Dr. 
Ledent, and their associates, Mr. Nanan, Mr. Lespagne, Mr. Caubergh, and Mr. Chappe; not to forget the territorial authorities who contributed to the success of the organization of our projects. Grateful acknowledgment is also made to Dr. K. Hummeler, Children's Hospital, Philadelphia, Pa., for his valuable help in the testing programme.

\section{REFERENCES}

Courtois, G., Koprowski, H., Ninane, G., Norton, T. W. and Osterrieth, P. (1958). Manuscript in preparation.

Gard, S. (1957). Arch. ges. Virusforsch., 7; 449.

Koprowsi. 26, 335.

(1957).

5. 128. G. A., and Norton, T. W. (1952). Amer. J. Hyg., 55, 108.

Norton, T. W., Hummeler, K., Stokes, J., jun., Hunt, A. D.; jun. Flack, A., and Jervis, G. A. (1956a). J. Amer. med. Ass., 162, 1281. J., and Meyer, K. F. (i956b). Ibid., 160, 954

Report of the Second Expert Committee on Poliomyelitis (1958). Wld Hlth Ort the Second Expert Committee on Po

Sabin, A. B. (1957). J. Amer. med. Ass., 164, 1216.

\section{ANOREXIA NERVOSA : A SOMATIC DISORDER}

\author{
BY
}

EIRIAN WILLIAMS, M.D., M.R.C.P. Senior Medical Registrar, The London Hospital

The results of treatment in anorexia nervosa are poor and have not benefited from its inclusion with the psychosomatic disorders (Cobb, 1950). Indeed, the approach to treatment has recently become confused owing to the mystery which now surrounds its aetiology, at one time explained in terms which, if superficial, at least were easily understood.

In his original description of the disease Sir William Gull (1874) attributed the want of appetite to a " morbid mental state," claiming that its origin is "central and not peripheral," and that the state might be called " hysterical without committing ourselves to the etymological value of the word, or maintaining that the subjects of it have the common symptoms of hysteria." He described his patients as "wilful, often allowed to drift their own way into a state of extreme exhaustion," in this way clearly implying that the illness is largely selfinduced. Samuel Gee (1907) described it as a melancholy - " no more than a high degree of the melancholy which affects so many girls about the age of puberty and for some years afterwards," arising, he said, "from a morbid excess of that craving for sympathy which is so common to all mankind, as is especially strong in the female sex." Ryle (1936), in his Schorstein Memorial Lecture, summarized the sequence of events in this way: "A psychic trauma or a foolish habit or some combination of the two results in a loss of appetite and a suppression of the menses. Starvation follows and with starvation an aggravation of the anorexia."

Ryle (1936) protested that "physicians subject to the lures of endocrinology have been tempted sometimes to find a basis for the symptoms of the disease in a primary deficiency or disharmony of the internal secretions." Psychiatrists, on the other hand, have claimed the illness in all its aspects as their own. History-taking has given way to psycho-analysis; physical findings are now ignored; and treatment has been ousted by therapy, either psychotherapy or electric convulsion, or both. Importance is attached to training in bowel habits at an unusually early age, to the relationship of "orality" to " sexuality" as in monkeys deprived of the uncus region of the brain (Sifneos, 1952), and even to the birth of Heitzi-eibib, a divine ancestor of the Hottentots, because a girl had swallowed the sap of grass (Waller et al. 1940).

These observations may be significant. Even so, anorexia nervosa is primarily a wasting disease, and when death occurs, as it does in a proportion of cases, it is directly due to malnutrition. Renourishment should therefore be the first object of treatment, and the problem is to decide how it can best be achieved.

\section{The Patients: Their Management and Progress}

Forty-nine females with anorexia nervosa were admitted to the wards of the London Hospital between 1897 and 1953, and four others are included who were admitted later (see Table).

Eleven were admitted on more than one occasion and three had previously been in hospital elsewhere. Marked weight loss and amenorrhoea were present in all, and, although many underwent extensive investigations, none showed evidence of primary organic disease. Both of the men in whom the diagnosis was made are excluded from the investigation.

Treatment.--Few patients were confined to bed, and for the majority no special diets were prescribed. The records do not reveal how much individual attention was given to each patient at meal-times, nor to what extent persuasion and discipline were applied. Dr. Stephen Mackenzie in 1897 , however, let it be known of his patient, who in three years had reduced in weight from 10 st. to $5 \mathrm{st} .8 \mathrm{lb}$. $(63.5$ to $35.4 \mathrm{~kg}$.) - " if she objects to food it is to be forced by means of a stomach pump." This she managed to avoid, unlike seven others, admitted later, who were intubated.

Immediate Results.-One patient who was comatose on admission died the following day. The rest were in hospital for periods ranging from 7 to 130 days, only five remaining for less than two weeks. The average length of stay was 42 days.

\section{Treatment Without Intubation}

Of those patients not intubated seven alone gained more than $14 \mathrm{lb}$. $(6.4 \mathrm{~kg}$.) in weight while in hospital, and in only five of these did it return to near normal. Seven patients continued to lose weight, one of them (Case 12) developing pulmonary tuberculosis during admission. It might be argued that many of those who gained a few pounds during a brief stay in hospital would have continued to improve had they remained longer. Other patients who were in for a month or more, however, showed a similar optimistic weight gain in the early weeks, only to relapse later. In assessing the value of treatment without intubation there were 57 such admissions, excluding that of the patient who died, and it must be concluded that at least 46 of them were fruitless.

\section{Treatment with Intubation}

On the other hand, good immediate results were obtained in the seven patients who submitted to intubation. All gained weight, the average being $22 \mathrm{lb}$. $(10 \mathrm{~kg}$.) per patient ; and the overall gain, in proportion to the time spent in hospital, would undoubtedly have been greater had they all been intubated early, instead of, as with some, after other methods had failed. Thus one patient (Case 14), in the first instance, was intubated for only 22 days, and, in her last admission, for only 31 days. Another (Case 20) was intubated on the 70th day of admission, and her stay could have been shortened accordingly. One patient (Case 53), on the other hand, began treatment on the third day and responded forthwith. She gained $41 \mathrm{lb}$. (18.6 kg.) in 28 days; her rapid progress is depicted in Fig. 1. All seven patients became stronger and happier as they gained weight, and the improvement in their mental outlook was as impressive as that in their bodily state. But this improvement was shortlived in one (Case 14) after her first admission, although in the end she recovered, and in another (Case 30) who eventually died (Fig. 2). 